Original paper

\title{
Accessory columbite to tantalite, tapiolite and zircon: products of extreme fractionation in highly peraluminous pegmatitic granite from the Považský Inovec Mountains, Western Carpathians, Slovakia
}

\author{
Peter CHUDÍK ${ }^{1, *}$, Pavel UHER¹, Milan KOHÚT², Peter BAČíK ${ }^{3}$ \\ ${ }^{1}$ Department of Mineral Deposits, Comenius University, Mlynská dolina, 84215 Bratislava, Slovakia; chudik@fns.uniba.sk \\ ${ }^{2}$ Dionýz Štúr State Geological Institute, Mlynská dolina 1, 81704 Bratislava, Slovakia \\ ${ }^{3}$ Department of Mineralogy and Petrology, Comenius University, Mlynská dolina, 84215 Bratislava, Slovakia \\ * Corresponding author
}

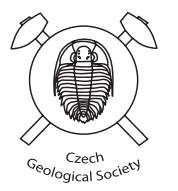

\begin{abstract}
Accessory Fe-rich columbite-group minerals, tapiolite and Hf-rich zircon occur in Hercynian pegmatitic leucogranite near Duchonka, Považský Inovec Mts., western Slovakia. The host rock represents highly peraluminous and fractionated S-type pegmatitic leucogranite with $\mathrm{ASI}=1.27, \mathrm{Eu}_{\mathrm{N}} / \mathrm{Eu}^{*}{ }_{\mathrm{N}}=0.16, \mathrm{Rb} / \mathrm{Sr}=7.2, \mathrm{Ta} / \mathrm{Nb}=1.1$ and Zr $/ \mathrm{Hf}=21$, but not enriched in Li, B, Be or P. Columbite-tantalite, tapiolite and hafnian zircon form discrete crystals, 30 to $350 \mu \mathrm{m}$ in size, in association with quartz, plagioclase, K-feldspar, muscovite, sillimanite, almandine-spessartine and fluorapatite. Columbite-tantalite crystals show coarse oscillatory zoning, usually with border parts enriched in Ta. Locally, there is a reversal trend of zoning (decrease of Ta towards the border parts), or irregular convoluted zoning as a result of latemagmatic to subsolidus dissolution-reprecipitation. The composition of columbite-tantalite shows a relatively constant $\mathrm{Mn} /(\mathrm{Mn}+\mathrm{Fe})$ ratio $(0.20-0.27$, locally $0.35-0.40)$, but extreme variations of the $\mathrm{Ta} /(\mathrm{Ta}+\mathrm{Nb})$ ratio $(0.18-0.72)$. Ratios higher than 0.63 plot inside the tantalite-tapiolite miscibility gap. Ferrotapiolite is mainly homogenous and shows relatively consistent compositions with $\mathrm{Mn} /(\mathrm{Mn}+\mathrm{Fe})=0.03-0.04$ and $\mathrm{Ta} /(\mathrm{Ta}+\mathrm{Nb})=0.88-0.97$. Metamict zircon ( 5 to $120 \mu \mathrm{m}$ in size) exhibits tiny uraninite inclusions, high $\mathrm{Hf}$ contents (6 to $23 \mathrm{wt}$ \% $\mathrm{HfO}_{2}, 0.06-0.23 \mathrm{Hf}$ apfu), and locally elevated $\mathrm{P}$, As and U contents, whereas $\mathrm{Y}$ and REE concentrations are low. Unusually widely variable and high $\mathrm{Ta} / \mathrm{Nb}$ and $\mathrm{Hf} / \mathrm{Zr}$ ratios in the accessory minerals are probably the product of extreme local $\mathrm{Nb}$ - $\mathrm{Ta}$ and $\mathrm{Zr}-\mathrm{Hf}$ fractionation in highly peraluminous granite-pegmatite system.
\end{abstract}

Keywords: ferrocolumbite, ferrotantalite, ferrotapiolite, hafnian zircon, Hercynian pegmatitic leucogranite, PovažskýInovec Mountains, Western Carpathians

Received: 1 October 2008; accepted 5 December 2008; handling editor: M. Novák

\section{Introduction}

Although uncommon, $\mathrm{Nb}$-Ta oxide minerals and Hf-rich zircon belong to the most characteristic accessory phases in evolved granitic rocks. They can reveal important information about the degree of melt fractionation and are useful tools for interpreting the P-T-X conditions of formation of their host rocks. The $\mathrm{Nb}$-Ta oxide minerals and hafnian zircon are usually found in highly evolved, specialized granites, commonly rich in volatile elements (F, B, P), and their greisenized cupolas, in association with cassiterite, wolframite, topaz, Li-silicates and other characteristic minerals (e.g., Johan and Johan 1994; Raimbault et al. 1995; Huang et al. 2002; Breiter et al. 2007). However, our knowledge of accessory Nb-Ta and $\mathrm{Zr}$-Hf phases in non-specialized, "barren" granites without $\mathrm{Li}, \mathrm{Be}, \mathrm{B}$ or $\mathrm{P}$ enrichment and $\mathrm{Sn} \pm \mathrm{W}$ mineralization is still very scarce in comparison to the specialized granites or rare-element granitic pegmatites.
In this article we describe accessory $\mathrm{Nb}$-Ta oxide minerals and Hf-rich zircon in such non-specialized S-type pegmatitic leucogranite near Duchonka, the Považský Inovec Mountains, Western Carpathians, Slovakia as an example of unusual $\mathrm{Nb}-\mathrm{Ta}$ and $\mathrm{Zr}$-Hf fractionation in highly peraluminous environment.

\section{Geological setting}

The Považský Inovec Mountain range represents the north-western part of the core mountain belt of the Inner (Central) Western Carpathians, a typical Miocene megaanticlinal horst that originated before 18-13 Ma (Danišík et al. 2004). It is elongated in the NNE-SSW direction. Mahel' (1986) distinguished three particular blocks of the Považský Inovec: northern - the Selec block, situated north of the Hrádok line, middle - the Bojná block, which extends between the Hrádok and the Koplotovce tectonic 
lines, and southern - the Hlohovec block, situated south of the Koplotovce line. The studied locality occurs in the eastern part of the Bojná block. Based on differences in the lithological and metamorphic setting, the crystalline basement in the Bojná block was divided into a Lower and an Upper structural level. The Lower structure of the crystalline basement consists of a relatively high-grade metamorphosed $\left(\mathrm{T}>550{ }^{\circ} \mathrm{C}, \mathrm{P}>350 \mathrm{MPa}\right)$ gneissic-amphibolitic complex with intrusions of two generations of granitic rocks (Ivanička et al. 2007). The protolith of the Lower metamorphic complex is Ordovician to Upper Silurian, and shows polymetamorphosed character. The upper structural level of the crystalline basement is formed by the younger, Devonian volcano-sedimentary Hlavinka Complex (Kohút et al. 2006), which is metamorphosed in lower grade $\left(\mathrm{T} \leq 500^{\circ} \mathrm{C}, \mathrm{P} \leq 300 \mathrm{MPa}\right)$ and without intrusive contacts with the Hercynian granitic rocks.

The acid magmatic rocks of the Bojná block are represented by the older granitoids of S-type (Lower Ordovician age), which were sheared to orthogneisses during the Hercynian orogeny, as well as the younger unsheared MesoHercynian granitoids of S-type (Lower- to Middle-Carboniferous age), which consist of biotite and muscovite-biotite granodiorites to granites, "non-homogenized - immature" hybrid granitoids - diatexites, as well as muscovite and biotite-muscovite leucocratic granites (Kamenický 1956; Broska and Uher 1988; Kohút et al. 2004).

The pegmatitic leucogranite examined in this study belongs to the younger, Meso-Hercynian suite. It occurs in a granite body situated between Podhradie and Duchonka, at the ridge between Lipová and Sol'nisko Hill, about $13 \mathrm{~km} \mathrm{NNW}$ of the town Topol'čany (Fig. 1),

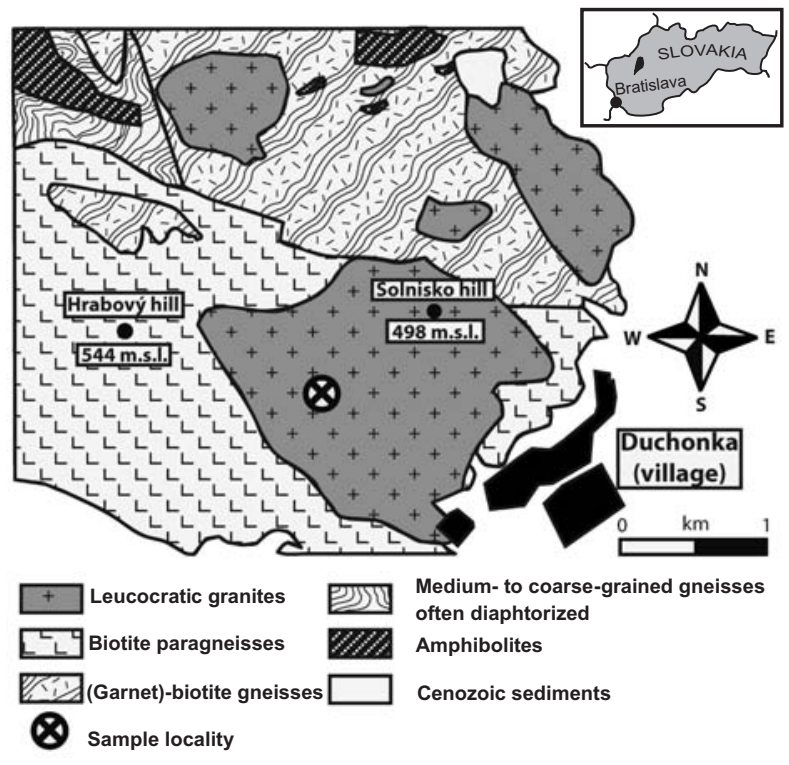

Fig. 1 Simplified geological map of the Duchonka region, Považský Inovec Mountains (modified from Ivanička et al. 2007). western Slovakia. The main body of biotite-muscovite (leuco-) granite is commonly cut by apophyses and dikes of pegmatitic leucogranite to granite pegmatite, usually 1 to $5 \mathrm{~m}$ thick. The studied sample represents an example of such pegmatitic leucogranite apophysis/dike.

\section{Analytical methods}

Electron-microprobe analyses (EMPA) were carried out in the wavelength-dispersion mode using the Cameca SX100 electron-microprobe at the State Geological Survey of Slovak Republic, Bratislava (Nb-Ta and silicate minerals) and an analogous instrument at the Institute of Geological Sciences, Masaryk University, Brno (zircon and apatite).

The following analytical conditions were used: accelerating voltage of $15 \mathrm{kV}$, a sample current of $20 \mathrm{nA}$, beam diameter of $1-3 \mu \mathrm{m}$ and a counting time of 20 to 40 s. For the $\mathrm{Nb}$-Ta minerals, the following standards were applied: metallic $\mathrm{W}(\mathrm{W} \mathrm{L} \alpha), \mathrm{LiNbO}_{3}(\mathrm{Nb} L \alpha), \mathrm{LiTaO}_{3}(\mathrm{Ta}$ $L \alpha), \mathrm{TiO}_{2}(\mathrm{Ti} K \alpha), \mathrm{SnO}_{2}(\mathrm{Sn} L \alpha), \mathrm{ZrSiO}_{4}(\mathrm{Zr} L \beta), \mathrm{ThO}_{2}$ (Th $M \alpha), \mathrm{UO}_{2}(\mathrm{U} M \beta), \mathrm{ScPO}_{4}(\mathrm{Sc} K \alpha), \mathrm{YPO}_{4}(\mathrm{Y} L \alpha), \mathrm{Sb}$ $(\mathrm{Sb} L \alpha)$, fayalite $(\mathrm{Fe} K \alpha)$, rhodonite $(\mathrm{Mn} \mathrm{K \alpha}), \mathrm{MgO}(\mathrm{Mg}$ $K \alpha)$, wollastonite $(\mathrm{Ca} K \alpha), \mathrm{ZnS}(\mathrm{Zn} \mathrm{K \alpha})$, and $\mathrm{PbS}(\mathrm{Pb}$ $M \alpha)$. For zircon, metallic $\mathrm{W}(\mathrm{W} L \alpha)$, apatite $(\mathrm{P} K \alpha, \mathrm{Ca}$ $K \alpha$ ), InAs (As $L \alpha$ ), ferrocolumbite ( $\mathrm{Nb} L \alpha$ ), titanite ( $\mathrm{Si}$ $K \alpha$, Ti $K \alpha$ ), zircon ( $\mathrm{Zr} L \alpha)$, metallic $\mathrm{Hf}(\mathrm{Hf} M \alpha)$, cheralite (Th $M \alpha$ ), metallic $\mathrm{U}(\mathrm{U} M \beta)$, sanidine (Al $K \alpha), \mathrm{ScVO}_{4}$ (Sc $K \alpha$ ), YAG (Y $L \alpha), \mathrm{CeAl}_{2}(\mathrm{Ce} L \alpha)$, Dy and Er glass (Dy $L \alpha, \mathrm{Er} L \alpha), \mathrm{YbP}_{5} \mathrm{O}_{14}(\mathrm{Yb} L \alpha)$, andradite $(\mathrm{Fe} K \alpha)$, rhodonite $(\mathrm{Mn} \mathrm{K \alpha})$, topaz $(\mathrm{F} \mathrm{K \alpha})$, and vanadinite $(\mathrm{Cl} \mathrm{K \alpha})$ standards were used. All data were reduced using the PAP routine (Pouchou and Pichoir 1985).

The rock was analyzed in the ACME Analytical Laboratories Ltd., Vancouver. Total abundances of the major oxides and several minor elements were analysed by ICP-emission spectrometry following a lithium metaborate/tetraborate fusion and dilute nitric digestion. Loss on ignition (LOI) is by weigh difference after ignition at $1000{ }^{\circ} \mathrm{C}$. Rare earth and refractory elements were determined by ICP mass spectrometry following a lithium metaborate/tetraborate fusion and nitric acid digestion of a $0.1 \mathrm{~g}$ sample. In addition a separate $0.5 \mathrm{~g}$ split was digested in aqua regia and analysed by ICP mass spectrometry. For other details see www.acmelab.com.

\section{Results}

\subsection{Mineral and chemical composition of the host pegmatitic leucogranite}

The pegmatitic leucogranite studied (sample PI-457b) is an equigranular, coarse-grained rock with the granitic 

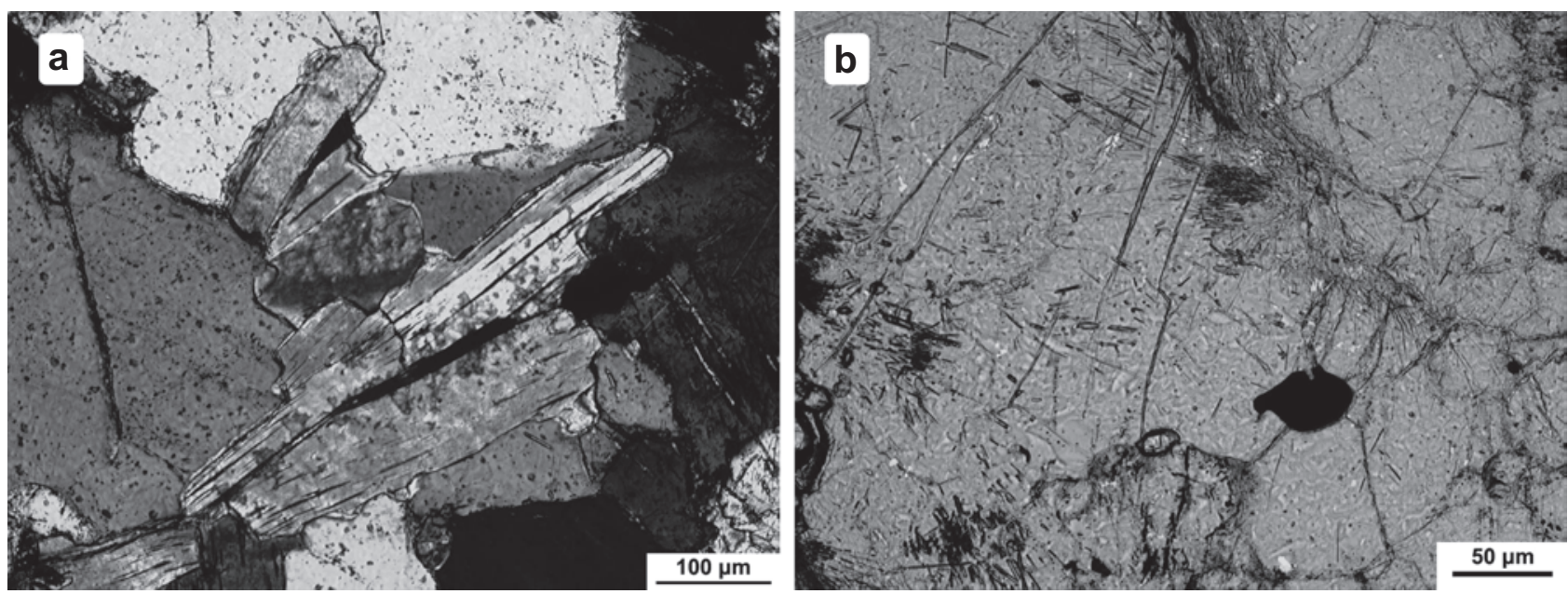

Fig. 2 Optical photomicrographs (transmitted light) of the Duchonka pegmatitic leucogranite (sample PI-457b) with Nb-Ta oxide minerals: a - Prismatic acicular crystal of columbite-tantalite (black inclusion in centre) in muscovite associated with quartz (left part) and plagioclase (right part). Crossed nicols. The length of columbite-tantalite is $\sim 0.1 \mathrm{~mm}$. b - Tapiolite inclusion (black) in quartz with fibrolitic sillimanite aggregate (upper and left part). Parallel nicols. The size of tapiolite is $\sim 0.07 \mathrm{~mm}$.

lepido-granoblastic texture. Its main mineral constituents are anhedral quartz, plagioclase $\left(\mathrm{An}_{04-28}\right)$, rare K-feldspar and muscovite (Fig. 2a). The muscovite shows usual composition with low $\mathrm{Rb}$ and $\mathrm{F}$ contents (c. 0.1 wt. \% $\mathrm{Rb}_{2} \mathrm{O}$ and $0.1-0.2$ wt. \% F, respectively). Common aggregates of fibrolitic sillimanite are intergrown with muscovite and quartz (Fig. 2b). Garnet forms euhedral to subhedral crystals (up to $3 \mathrm{~mm}$ in size), in association with quartz, alkali feldspar, muscovite and apatite. It shows almandine-spessartine composition with a small admixture of the pyrope and grossular end-members $\left(\mathrm{Alm}_{52-61} \mathrm{Sps}_{31-44} \operatorname{Prp}_{03-06} \mathrm{Grs}_{00-03}\right)$, locally a slight $\mathrm{Mn} / \mathrm{Fe}$ enrichment in rim parts and up to 0.6 wt. $\% \mathrm{P}_{2} \mathrm{O}_{5}(0.04 \mathrm{P}$ apfu). Apatite occurs as anhedral inclusions in the garnet $(100-150 \mu \mathrm{m}$ in size) or widespread discrete prismatic crystals (up to $400 \mu \mathrm{m}$ across) in association with quartz, plagioclase, muscovite, garnet and zircon. It shows relatively homogeneous fluorapatite composition with $0.78-0.94 \mathrm{~F}$ apfu, up to 0.6 wt. $\% \mathrm{MnO}(\leq 0.04 \mathrm{Mn}$ apfu $)$ and up to 0.3 wt. $\% \mathrm{FeO}(\leq 0.02 \mathrm{Fe}$ apfu). An accessory Ti-phase in muscovite (probably rutile), a Fe-phase (probably magnetite), a Fe-S mineral (probably pyrite), thorianite and barite were identified by EMPA occasionally, besides zircon and $\mathrm{Nb}$-Ta oxide minerals.

The studied rock is geochemically characterized as relatively strongly peraluminous and highly fractionated pegmatitic leucogranite with S-type characteristics. High $\mathrm{Si}, \mathrm{Al}, \mathrm{Na}$, moderate $\mathrm{K}$ and $\mathrm{P}$, and low $\mathrm{Ti}, \mathrm{Fe}, \mathrm{Mg}$ and $\mathrm{Ca}$ contents are typical features of the rock (Tab. 1). The aluminium saturation index (ASI, or molar $\mathrm{Al} /(\mathrm{Ca}+\mathrm{Na}$ $+\mathrm{K})$ ) of the rock attains a value of 1.27 and indicates its relatively strong peraluminous character (Fig. 3). Concentrations of index trace elements show elevated $\mathrm{Ta}$ and $\mathrm{Nb}$,
Tab. 1 Chemical composition of the Duchonka pegmatitic granite (sample PI-457b)

\begin{tabular}{|c|c|c|c|}
\hline & wt. \% & & $\mathrm{ppm}$ \\
\hline $\mathrm{SiO}_{2}$ & 74.05 & $\mathrm{Li}$ & 35 \\
\hline $\mathrm{TiO}_{2}$ & 0.17 & $\mathrm{Rb}$ & 173 \\
\hline $\mathrm{Al}_{2} \mathrm{O}_{3}$ & 15.16 & Cs & 6.0 \\
\hline $\mathrm{Fe}_{2} \mathrm{O}_{3}$ & 0.53 & $\mathrm{Sr}$ & 24 \\
\hline $\mathrm{FeO}$ & 0.28 & $\mathrm{Ba}$ & 45 \\
\hline $\mathrm{MnO}$ & 0.04 & $\mathrm{Be}$ & 2.5 \\
\hline $\mathrm{MgO}$ & 0.09 & B & 8.0 \\
\hline $\mathrm{CaO}$ & 0.34 & $\mathrm{Ga}$ & 18 \\
\hline $\mathrm{Na}_{2} \mathrm{O}$ & 4.76 & Sn & 3.0 \\
\hline $\mathrm{K}_{2} \mathrm{O}$ & 3.23 & $\mathrm{Zr}$ & 21 \\
\hline $\mathrm{P}_{2} \mathrm{O}_{5}$ & 0.16 & $\mathrm{Hf}$ & 1.0 \\
\hline LOI & 0.71 & $\mathrm{Nb}$ & 18.5 \\
\hline $\mathrm{H}_{2} \mathrm{O}^{-}$ & 0.19 & $\mathrm{Ta}$ & 21.0 \\
\hline \multirow[t]{2}{*}{ Total } & 99.71 & Mo & 0.8 \\
\hline & ppm & & ppm \\
\hline As & 0.75 & $\mathrm{Ce}$ & 4.55 \\
\hline $\mathrm{Cr}$ & 5.0 & $\operatorname{Pr}$ & 0.55 \\
\hline V & 5.5 & $\mathrm{Nd}$ & 2.20 \\
\hline $\mathrm{Ni}$ & 0.5 & $\mathrm{Sm}$ & 0.65 \\
\hline Co & 6.0 & $\mathrm{Eu}$ & 0.04 \\
\hline $\mathrm{Zn}$ & 16 & Gd & 0.90 \\
\hline $\mathrm{Cu}$ & 4.0 & $\mathrm{~Tb}$ & 0.15 \\
\hline $\mathrm{Pb}$ & 11 & Dy & 0.95 \\
\hline Th & 3.0 & Но & 0.20 \\
\hline $\mathrm{U}$ & 3.0 & Er & 0.45 \\
\hline $\mathrm{Sc}$ & 1.0 & $\mathrm{Tm}$ & 0.07 \\
\hline Y & 5.75 & $\mathrm{Yb}$ & 0.05 \\
\hline $\mathrm{La}$ & 2.15 & $\mathrm{Lu}$ & 0.06 \\
\hline
\end{tabular}




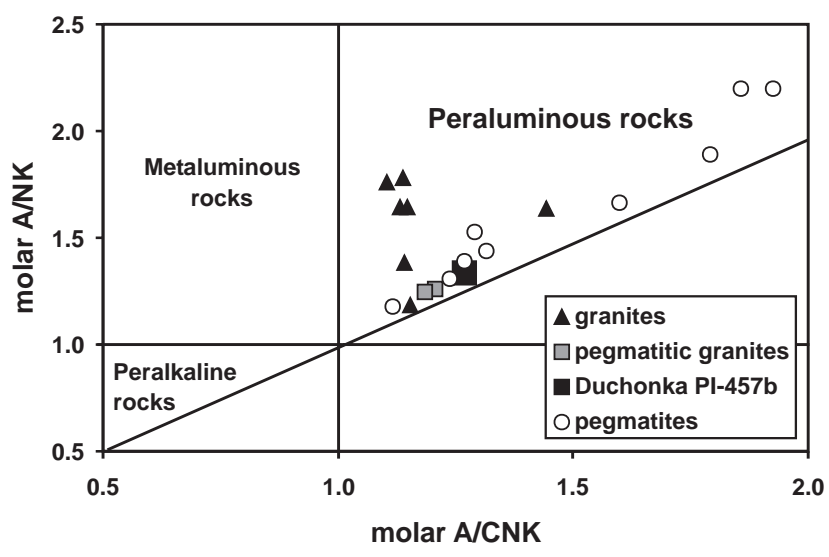

Fig. 3 The A/NK vs. A/CNK diagram for the Duchonka pegmatitic leucogranite (sample PI-457b) in comparison to the adjacent granites, pegmatitic granites and granitic pegmatites of the Bojná and Sol'nisko massifs, Považský Inovec Mountains (unpublished analyses of the authors). $\mathrm{A} / \mathrm{NK}=\mathrm{Al} /(\mathrm{Na}+\mathrm{K}), \mathrm{A} / \mathrm{CNK}=\mathrm{Al} /(\mathrm{Ca}+\mathrm{Na}+\mathrm{K})$ (millications).

moderate $\mathrm{Li}, \mathrm{Rb}, \mathrm{Cs}, \mathrm{Be}, \mathrm{Ga}, \mathrm{Sn}$ and $\mathrm{U}$, as well as low $\mathrm{Sr}$, $\mathrm{Ba}, \mathrm{B}, \mathrm{REE}, \mathrm{Zr}$, Hf and Th contents (Tab. 1). Moreover, high $\mathrm{Rb} / \mathrm{Sr}=7.2$, and especially unusually high values of $\mathrm{Ta} / \mathrm{Nb}=1.1$ and low $\mathrm{Zr} / \mathrm{Hf}=21$, together with distinctly negative Eu-anomaly $\left(\mathrm{Eu}_{\mathrm{N}} / \mathrm{Eu}^{*}{ }_{\mathrm{N}}=0.16\right)$ provide an evidence for a relatively high degree of magmatic fractionation of the investigated pegmatitic leucogranite compared to other granitic rocks in the Považský Inovec Mountains (Fig. 4).

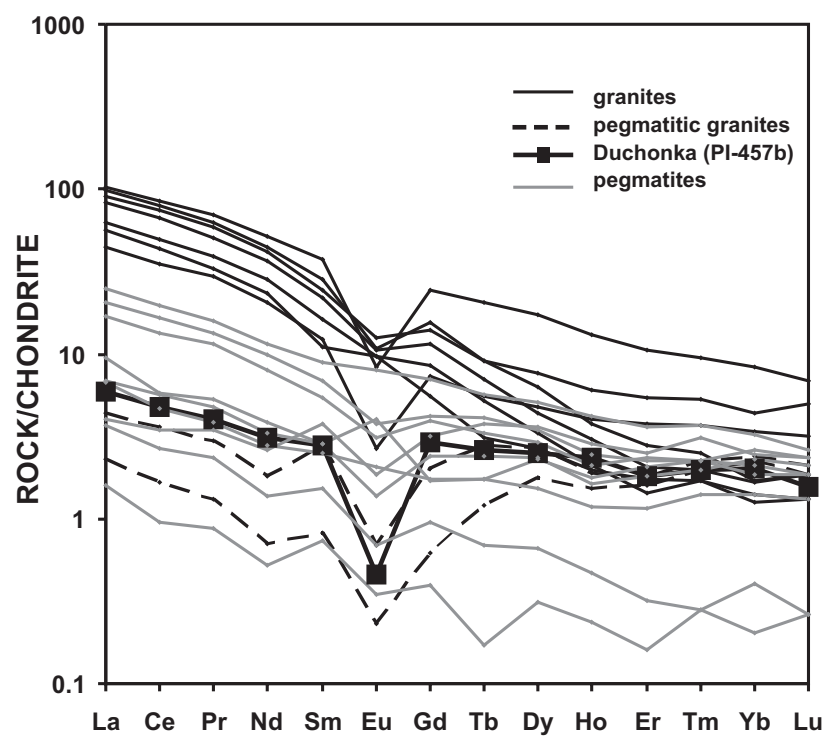

Fig. 4 The chondrite-normalized REE diagram for the Duchonka pegmatitic leucogranite (sample PI-457b). For comparison are plotted adjacent granites, pegmatitic granites and granitic pegmatites of the Bojná and Sol'nisko massifs, Považský Inovec Mountains (unpublished analyses of the authors). Chondrite values after Taylor and McLennan (1985).

\subsection{Niobium-tantalum oxide minerals}

Columbite-group minerals form discrete tabular crystals $30-350 \mu \mathrm{m}$ in size, in association with quartz, alkalifeldspar, muscovite and sillimanite (Figs 2a, 5a-b). The grains commonly show prograde zoning with central parts enriched in $\mathrm{Nb}$ (ferrocolumbite) and rims enriched in $\mathrm{Ta}$ (ferrotantalite). However, an irregular convoluted zoning of border parts, as a result of late-magmatic to subsolidus dissolution-reprecipitation processes is also present (Figs $5 \mathrm{c}-\mathrm{d}$ ), or a reversed trend of zoning with decrease of Ta towards the border parts of the crystals was detected (Fig. 5e). The composition of columbite-tantalite shows a relatively constant $\mathrm{Mn} /(\mathrm{Mn}+\mathrm{Fe})=0.20-0.27$ (locally $0.35-0.40)$, but an extreme range of $\mathrm{Nb}$-Ta fractionation $(\mathrm{Ta} /(\mathrm{Ta}+\mathrm{Nb})=0.18-0.72)$. Moreover, some analyses in the rim of the tantalite crystals show a $\mathrm{Ta} /(\mathrm{Ta}+\mathrm{Nb})$ ratio above 0.63 and plot in the field of the miscibility gap between tantalite and tapiolite (Tab. 2, Figs 5f, 6). Contents of Ti, W, Sn, Mg and other elements in studied columbite to tantalite are low. Titanium attains mostly about 0.5 wt. $\% \mathrm{TiO}_{2}$ and a slight decrease of $\mathrm{Ti}$ with increasing values of $\mathrm{Ta} /(\mathrm{Ta}+\mathrm{Nb})$ was recorded. Locally slightly elevated $\mathrm{Zr}$ and $\mathrm{Pb}$ contents were noted $(\leq 0.6$ wt. $\% \mathrm{ZrO}_{2}$ and $\leq 1.2$ wt. $\% \mathrm{PbO}$ ) but they represent only up to 0.02 apfu and do not influence significantly crystal chemistry of the columbite-tantalite.

Ferrotapiolite forms discrete irregular or shortly prismatic crystals, c. $15-75 \mu \mathrm{m}$ in size, in association with quartz and sillimanite (Figs 2b, 7a). The ferrotapiolite displays slightly irregular compositional zoning in a BSE image with $\mathrm{Mn} /(\mathrm{Mn}+\mathrm{Fe})=0.03-0.04$ and $\mathrm{Ta} /(\mathrm{Ta}$ $+\mathrm{Nb}$ ) $=0.88-0.97$ (Figs 7b-c, Tab. 2). The Ti and $\mathrm{Sn}$ contents are slightly higher than in the co-existing columbite-group minerals $\left(\mathrm{SnO}_{2} \leq 0.8\right.$ wt. $\%$ and $\mathrm{TiO}_{2} \leq$ 1.3 wt. \%).

In view of the low contents of $\mathrm{W}, \mathrm{Ti}, \mathrm{Sn}, \mathrm{Zr}, \mathrm{Mg}, \mathrm{Pb}$ and other elements, we conclude that only the single $\mathrm{TaNb}_{-1}$ and $\mathrm{MnFe}_{-1}$ substitutions, separately or in combination, are relevant to compositional changes for both the columbite-tantalite and the tapiolite.

\subsection{Hafnian zircon}

Accessory zircon forms euhedral to subhedral, columnar prismatic crystals, 5 to $120 \mu \mathrm{m}$ long, included in quartz or muscovite (Fig. 7a). In BSE, zircon usually displays a slightly diffuse zoning with a darker center and a brighter rim zone (Fig. 7d), probably mainly due to variations in $\mathrm{Hf}$ and $\mathrm{U}$ concentrations and/or different metamictization degree. The central parts commonly contain numerous oval inclusions of uraninite, c. 0.7 to $2 \mu \mathrm{m}$ across (Fig. 7d). Zircon shows distinct $\mathrm{Hf}$ enrichment, $\mathrm{HfO}_{2}$ concentrations vary between 6 and 23 wt. \%, 0.06-0.23 Hf 

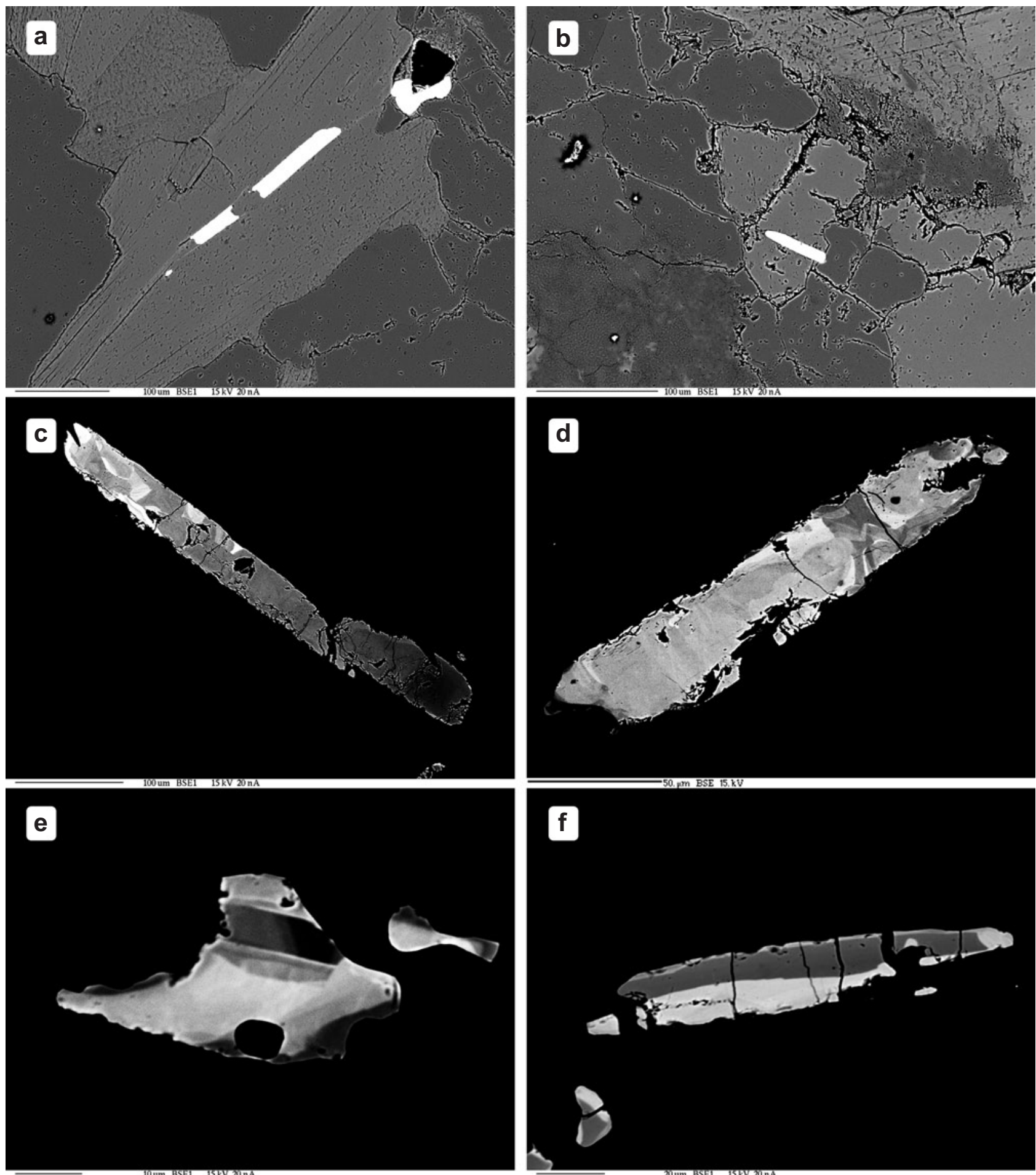

III

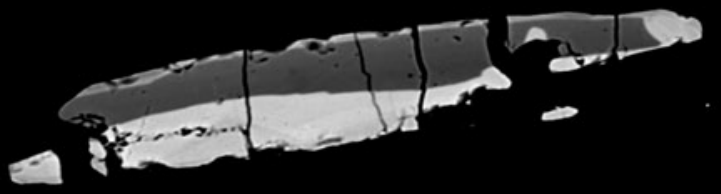

Fig. 5 Back-scattered electron (BSE) images of columbite-tantalite from the Duchonka pegmatitic leucogranite. a - columbite-tantalite crystals (white) in muscovite (light grey) in association with quartz (dark grey). b - columbite-tantalite crystal (white) in plagioclase (light grey) in association with quartz (dark grey) and muscovite (medium grey, right part). c and $\mathbf{d}$ - columnar columbite-tantalite crystals with irregular zoning caused by late-magmatic to subsolidus partial dissolution-reprecipitation processes. e - combination of concentric progressive zoning (dark $\mathrm{Nb}$-rich core and light Ta-rich intermediate zone) with late reverse zoning (Nb-rich rim zone) of columbite-tantalite crystal. $\mathbf{f}-$ columnar crystal with a core of ferrocolumbite (grey) surrounded by younger (white) rim of ferrotantalite composition falling into the tantalite-tapiolite miscibility gap (see text). 
Tab. 2 Representave compositions of ferrocolumbite (Fe-Col), ferrotantalite (Fe-Tan), ferrotantalite in the miscibility gap field (Fe-Tan X) and ferrotapiolite (Fe-Tap) from the Duchonka pegmatitic leucogranite (in wt. \%)

\begin{tabular}{|c|c|c|c|c|c|c|c|c|}
\hline & $\mathrm{Fe}-\mathrm{Col}$ & Fe-Tan & Fe-Tan & Fe-Tan X & Fe-Tan X & Fe-Tan X & Fe-Tap & Fe-Tap \\
\hline $\mathrm{WO}_{3}$ & 0.25 & 0.10 & 0.00 & 0.15 & 0.05 & 0.00 & 0.12 & 0.17 \\
\hline $\mathrm{Nb}_{2} \mathrm{O}_{5}$ & 41.66 & 25.36 & 20.83 & 21.79 & 17.94 & 15.88 & 6.14 & 1.58 \\
\hline $\mathrm{Ta}_{2} \mathrm{O}_{5}$ & 39.81 & 58.90 & 63.45 & 62.44 & 66.56 & 68.18 & 78.91 & 83.22 \\
\hline $\mathrm{TiO}_{2}$ & 0.07 & 0.09 & 0.04 & 0.46 & 0.16 & 0.44 & 1.28 & 0.83 \\
\hline $\mathrm{SnO}_{2}$ & 0.07 & 0.00 & 0.18 & 0.17 & 0.00 & 0.13 & 0.46 & 0.45 \\
\hline $\mathrm{ZrO}_{2}$ & 0.25 & 0.06 & 0.24 & 0.24 & 0.05 & 0.24 & 0.21 & 0.12 \\
\hline $\mathrm{Sc}_{2} \mathrm{O}_{3}$ & 0.00 & 0.03 & 0.00 & 0.00 & 0.01 & 0.00 & 0.00 & 0.00 \\
\hline $\mathrm{Y}_{2} \mathrm{O}_{3}$ & 0.00 & 0.00 & 0.04 & 0.02 & 0.04 & 0.00 & 0.00 & 0.00 \\
\hline $\mathrm{Sb}_{2} \mathrm{O}_{3}$ & 0.06 & 0.10 & 0.00 & 0.03 & 0.00 & 0.04 & 0.10 & 0.05 \\
\hline $\mathrm{Fe}_{2} \mathrm{O}_{3}$ calc. & 0.00 & 0.00 & 0.00 & 0.00 & 0.00 & 0.00 & 0.00 & 0.00 \\
\hline $\mathrm{FeO}$ & 11.73 & 10.57 & 9.22 & 10.65 & 9.89 & 10.14 & 12.31 & 11.90 \\
\hline $\mathrm{MnO}$ & 4.22 & 3.81 & 5.22 & 3.05 & 3.66 & 2.90 & 0.48 & 0.41 \\
\hline $\mathrm{MgO}$ & 0.16 & 0.19 & 0.02 & 0.28 & 0.23 & 0.26 & 0.00 & 0.00 \\
\hline $\mathrm{CaO}$ & 0.02 & 0.02 & 0.02 & 0.01 & 0.04 & 0.00 & 0.01 & 0.00 \\
\hline $\mathrm{PbO}$ & 0.58 & 0.21 & 0.23 & 0.43 & 0.36 & 0.27 & 0.00 & 0.02 \\
\hline Total & 98.31 & 99.22 & 99.26 & 99.31 & 98.63 & 98.21 & 100.07 & 98.73 \\
\hline \multicolumn{9}{|c|}{ Formulae based on 6 oxygen atoms and valence calculation } \\
\hline W & 0.004 & 0.002 & 0.000 & 0.003 & 0.001 & 0.000 & 0.002 & 0.004 \\
\hline $\mathrm{Nb}$ & 1.275 & 0.844 & 0.712 & 0.735 & 0.626 & 0.561 & 0.225 & 0.061 \\
\hline $\mathrm{Ta}$ & 0.733 & 1.179 & 1.304 & 1.268 & 1.397 & 1.450 & 1.740 & 1.925 \\
\hline $\mathrm{Ti}$ & 0.004 & 0.005 & 0.002 & 0.026 & 0.009 & 0.026 & 0.078 & 0.053 \\
\hline $\mathrm{Sn}$ & 0.002 & 0.000 & 0.005 & 0.005 & 0.000 & 0.004 & 0.015 & 0.015 \\
\hline Sum $B$ & 2.019 & 2.030 & 2.023 & 2.037 & 2.033 & 2.041 & 2.061 & 2.058 \\
\hline $\mathrm{Zr}$ & 0.008 & 0.002 & 0.009 & 0.009 & 0.002 & 0.009 & 0.008 & 0.005 \\
\hline $\mathrm{Sc}$ & 0.000 & 0.002 & 0.000 & 0.000 & 0.001 & 0.000 & 0.000 & 0.000 \\
\hline $\mathrm{Y}$ & 0.000 & 0.000 & 0.002 & 0.001 & 0.002 & 0.000 & 0.000 & 0.000 \\
\hline $\mathrm{Sb}$ & 0.002 & 0.003 & 0.000 & 0.001 & 0.000 & 0.001 & 0.003 & 0.002 \\
\hline $\mathrm{Fe}^{3+}$ & 0.000 & 0.000 & 0.000 & 0.000 & 0.000 & 0.000 & 0.000 & 0.000 \\
\hline $\mathrm{Fe}^{2+}$ & 0.664 & 0.651 & 0.583 & 0.665 & 0.638 & 0.663 & 0.835 & 0.846 \\
\hline $\mathrm{Mn}$ & 0.242 & 0.237 & 0.334 & 0.193 & 0.239 & 0.192 & 0.033 & 0.029 \\
\hline $\mathrm{Mg}$ & 0.016 & 0.021 & 0.002 & 0.031 & 0.026 & 0.031 & 0.000 & 0.000 \\
\hline $\mathrm{Ca}$ & 0.002 & 0.002 & 0.002 & 0.001 & 0.004 & 0.000 & 0.001 & 0.000 \\
\hline $\mathrm{Pb}$ & 0.011 & 0.004 & 0.005 & 0.009 & 0.007 & 0.006 & 0.000 & 0.000 \\
\hline Sum $A$ & 0.944 & 0.922 & 0.936 & 0.909 & 0.919 & 0.902 & 0.880 & 0.882 \\
\hline $\operatorname{Sum} A+B$ & 2.963 & 2.952 & 2.959 & 2.946 & 2.952 & 2.943 & 2.942 & 2.940 \\
\hline $\mathrm{Mn} /(\mathrm{Mn}+\mathrm{Fe})$ & 0.267 & 0.267 & 0.364 & 0.225 & 0.272 & 0.225 & 0.038 & 0.033 \\
\hline $\mathrm{Ta} /(\mathrm{Ta}+\mathrm{Nb})$ & 0.365 & 0.583 & 0.647 & 0.633 & 0.691 & 0.721 & 0.885 & 0.969 \\
\hline
\end{tabular}

Contents of $\mathrm{Th}, \mathrm{U}$ and $\mathrm{Zn}$ are below the detection limit.

Fig. 7 BSE photomicrographs of ferrotapiolite and hafnian zircon from the Duchonka pegmatitic leucogranite. a - ferrotapiolite (larger white) and zircon (smaller white) inclusions in quartz (dark grey) in association with plagioclase (medium grey) and muscovite (light grey). b and c - irregularly zoned ferrotapiolite crystals. The zoning reflects slight $\mathrm{Ta}-\mathrm{Nb}$ compositional variations. d - columnar metamict, slightly zoned hafnian zircon with numerous uraninite inclusions (white). 


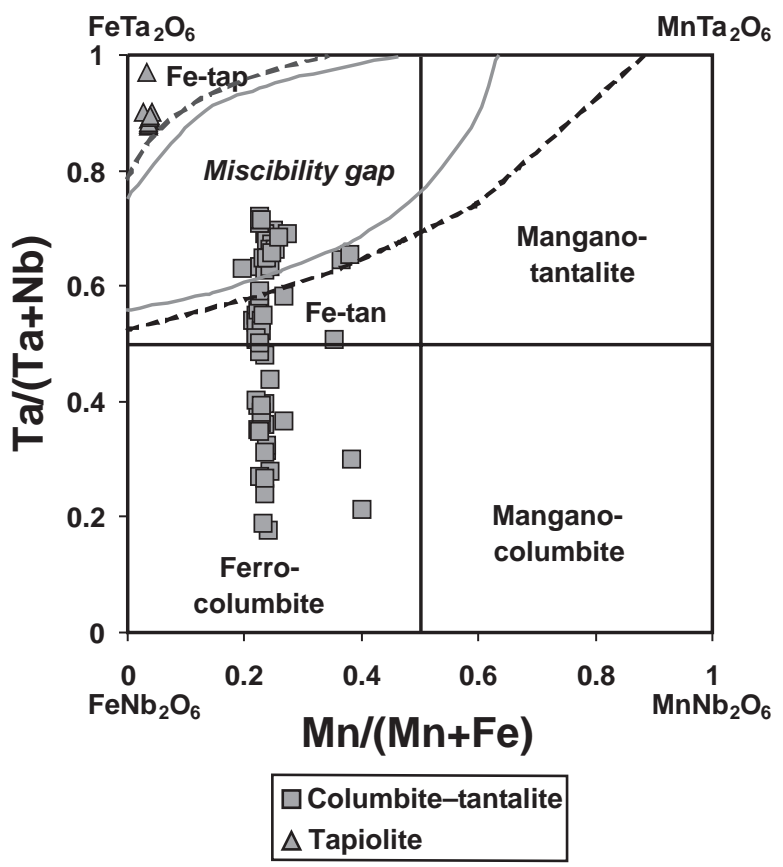

apfu (Tab. 3). Therefore, $\mathrm{HfZr}_{-1}$ is the principal substitution in the hafnian zircon (Fig. 8). However, increased contents of $\mathrm{P}\left(\mathrm{P}_{2} \mathrm{O}_{5} \leq 0.9\right.$ wt. \%), As $\left(\mathrm{As}_{2} \mathrm{O}_{5} \leq 0.7\right.$ wt. \%) and $\mathrm{U}\left(\mathrm{UO}_{2} \leq 1.4\right.$ wt. \%), together with slightly elevated amounts of $\mathrm{Fe}$ and $\mathrm{Ca}$ were detected locally (Tab. 3). On the other hand, concentrations of $\mathrm{Y}, \mathrm{REE}$ and $\mathrm{Al}$ are usually negligible to low. The apparent discrepancy between the presence of pentavalent cations ( $\mathrm{P}$ and As) and paucity of trivalent cations (such as $\mathrm{Y}, \mathrm{REE}, \mathrm{Al}$ and $\mathrm{Sc}$ ) could be explained by partial leaching of some elements during metamictization and structural degradation of the zircon and/or analytical errors of EMPA at low elemental concentrations.

穴

Fig. 6 Quadrilateral diagram of columbite-tantalite and tapiolite from the Duchonka pegmatitic leucogranite. The boundaries of the tantalite-tapiolite miscibility gap are taken for single-phase, non-paired compositions of tantalite and tapiolite (grey solid line, after Černý and Ercit 1989) and coexisting tantalite-tapiolite pairs (black dashed line, after Černý et al. 1992a). Abbreviations: Fe-tan - ferrotantalite, Fe-tap - ferrotapiolite.
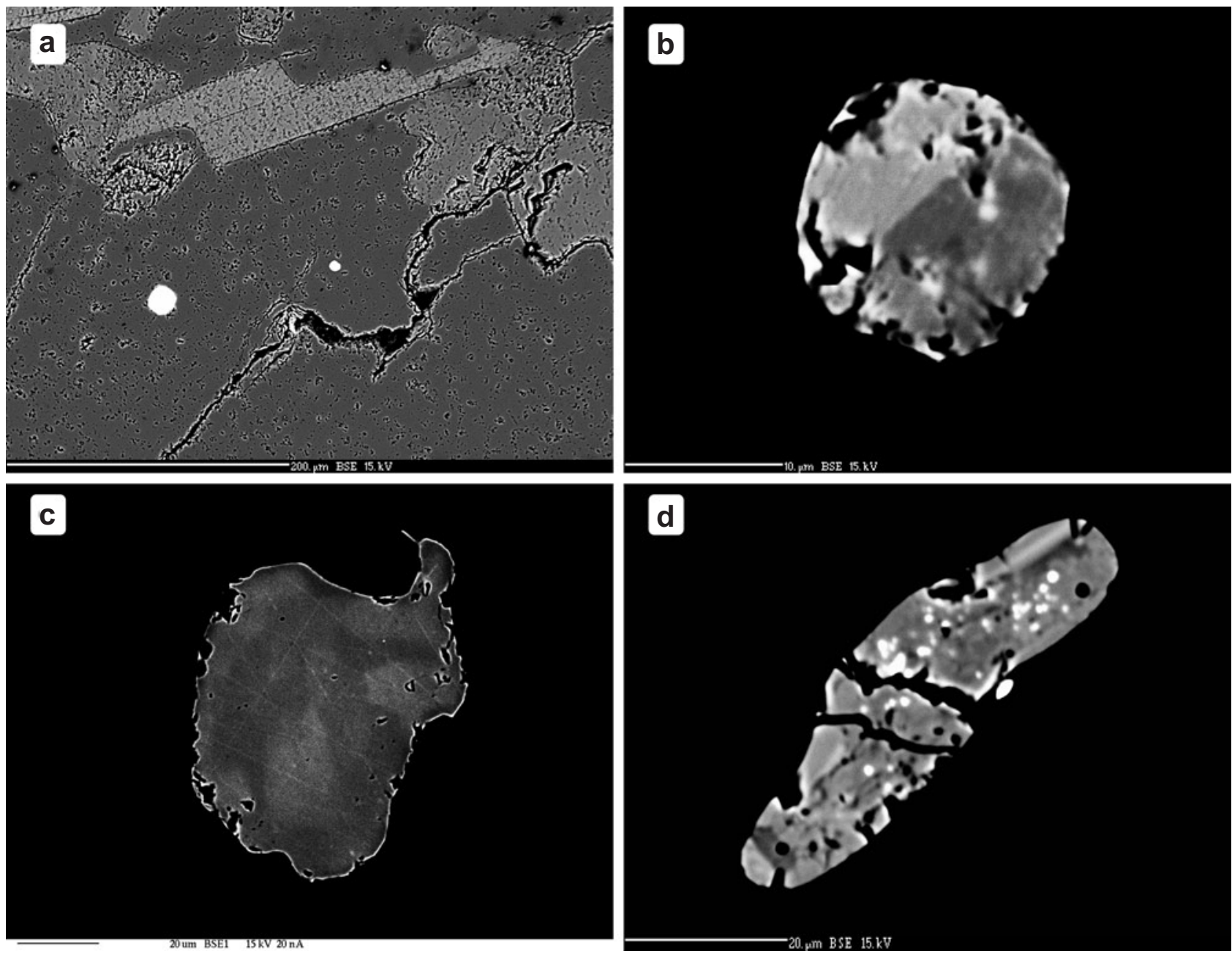


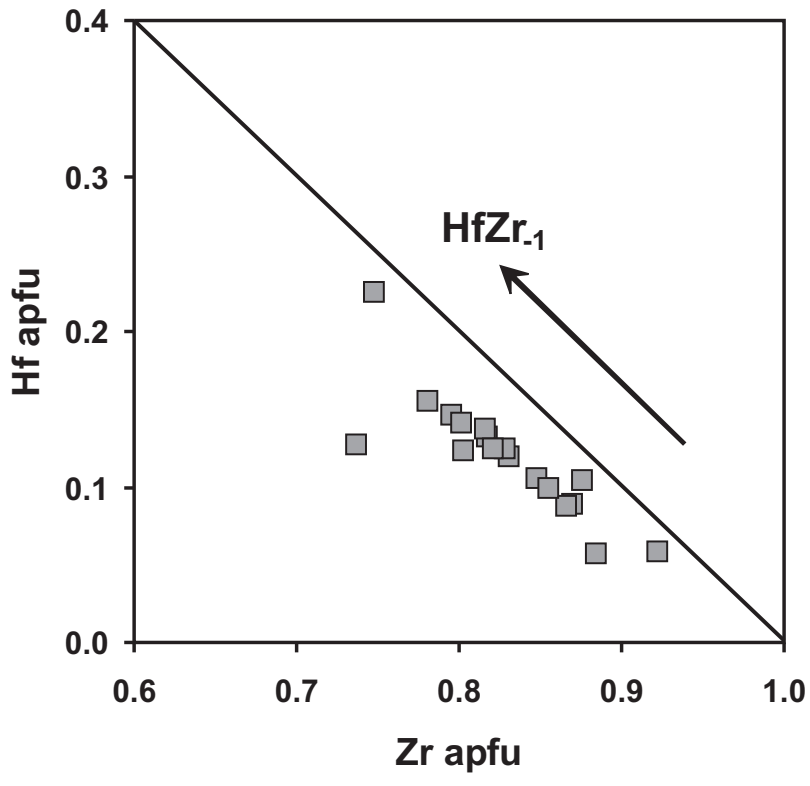

Fig. 8 The Hf vs. Zr substitution diagram for hafnian zircon from the Duchonka pegmatitic leucogranite (atomic proportions).

\section{Discussion and conclusion}

\subsection{Regional importance of $\mathrm{Nb}-\mathrm{Ta}$ and $\mathrm{Zr}-\mathrm{Hf}$ mineralization}

The disseminated $\mathrm{Nb}-\mathrm{Ta}$ and $\mathrm{Zr}$-Hf mineralization, which occurs in the fractionated, peraluminous sillimanite-bearing pegmatitic leucogranite apophysis/dike at Duchonka, represents a new genetic type of mineralization in the Považský Inovec Mountains, as well as in the whole West Carpathian area. The occurrence of fibrolitic sillimanite intergrown with primary muscovite and garnet of the almandine-spessartine composition documents the strongly peraluminous character of the host pegmatitic leucogranite $(\mathrm{ASI}=1.27$; Tab. 1, Figs 2b, 3). Similar occurrences of fibrolitic sillimanite were documented in different granodioritic to leucogranitic rocks in the Považský Inovec Mountains (Broska and Uher 1988). Apparently, the $\mathrm{Nb}$-Ta oxides and other accessory minerals did not suffer any strong post-Hercynian metamorphic overprint and, consequently, they represent primary magmatic to early

Tab. 3 Representative compositions of zircon from the Duchonka pegmatitic leucogranite (in wt. \%)

\begin{tabular}{|c|c|c|c|c|c|c|c|}
\hline & Crystal 1 & Crystal 2 & Crystal 3 & Formulae & 4 oxyg & & \\
\hline $\mathrm{P}_{2} \mathrm{O}_{5}$ & 0.94 & 0.01 & 0.25 & $\mathrm{P}$ & 0.026 & 0.000 & 0.007 \\
\hline $\mathrm{As}_{2} \mathrm{O}_{5}$ & 0.19 & 0.35 & 0.73 & As & 0.003 & 0.006 & 0.013 \\
\hline $\mathrm{SiO}_{2}$ & 30.65 & 31.49 & 28.61 & $\mathrm{Si}$ & 0.982 & 1.006 & 0.982 \\
\hline $\mathrm{ZrO}_{2}$ & 56.60 & 56.26 & 44.67 & Sum $B$ & 1.011 & 1.012 & 1.002 \\
\hline $\mathrm{HfO}_{2}$ & 6.19 & 11.51 & 23.00 & & & & \\
\hline $\mathrm{UO}_{2}$ & 1.26 & 0.13 & 1.41 & $\mathrm{Zr}$ & 0.884 & 0.876 & 0.748 \\
\hline $\mathrm{Al}_{2} \mathrm{O}_{3}$ & 0.18 & 0.02 & 0.06 & $\mathrm{Hf}$ & 0.057 & 0.105 & 0.225 \\
\hline $\mathrm{Y}_{2} \mathrm{O}_{3}$ & 0.92 & 0.00 & 0.00 & $\mathrm{U}$ & 0.009 & 0.001 & 0.011 \\
\hline $\mathrm{Ce}_{2} \mathrm{O}_{3}$ & 0.06 & 0.05 & 0.00 & $\mathrm{Al}$ & 0.007 & 0.001 & 0.002 \\
\hline $\mathrm{Dy}_{2} \mathrm{O}_{3}$ & 0.30 & 0.04 & 0.14 & Y & 0.016 & 0.000 & 0.000 \\
\hline $\mathrm{Er}_{2} \mathrm{O}_{3}$ & 0.04 & 0.13 & 0.24 & $\mathrm{Ce}$ & 0.001 & 0.001 & 0.000 \\
\hline $\mathrm{FeO}$ & 0.39 & 0.04 & 0.04 & Dy & 0.003 & 0.000 & 0.002 \\
\hline $\mathrm{MnO}$ & 0.14 & 0.00 & 0.08 & Er & 0.000 & 0.001 & 0.003 \\
\hline $\mathrm{CaO}$ & 0.23 & 0.02 & 0.01 & $\mathrm{Fe}$ & 0.010 & 0.001 & 0.001 \\
\hline F & 0.00 & 0.00 & 0.00 & $\mathrm{Mn}$ & 0.004 & 0.000 & 0.002 \\
\hline $\mathrm{Cl}$ & 0.04 & 0.00 & 0.11 & $\mathrm{Ca}$ & 0.008 & 0.001 & 0.000 \\
\hline $\mathrm{O}=\mathrm{F}$ & 0.00 & 0.00 & 0.00 & $\operatorname{Sum} A$ & 0.999 & 0.987 & 0.994 \\
\hline $\mathrm{O}=\mathrm{Cl}$ & -0.01 & 0.00 & -0.02 & & & & \\
\hline Total & 98.12 & 100.05 & 99.33 & $\operatorname{Sum} A+B$ & 2.010 & 2.000 & 1.997 \\
\hline $\mathrm{ZrO}_{2} / \mathrm{HfO}_{2}$ & 9.14 & 4.89 & 1.94 & $\mathrm{Cl}$ & 0.002 & 0.000 & 0.006 \\
\hline $\mathrm{Zr} / \mathrm{Hf}$ weight & 8.48 & 4.53 & 1.80 & $\mathrm{O}$ & 3.998 & 4.000 & 3.994 \\
\hline $100 \mathrm{Hf} /(\mathrm{Hf}+\mathrm{Zr})$ at. & 6.06 & 10.70 & 23.12 & & & & \\
\hline
\end{tabular}

Contents of $\mathrm{W}, \mathrm{Ti}$, Th, Sc, Yb, Bi and $\mathrm{F}$ are below the detection limit. 
post-magmatic textural and compositional features rather than relicts of any progressive metamorphic overprint. On the contrary, effects of a prograde, sillimanite-grade metamorphism on an older granitic pegmatite are known for example from Maršíkov, Czech Republic (Černý et al. 1992b), where took place extensive compositional and structural re-equilibration of the $\mathrm{Nb}$-Ta oxide minerals and breakdown of beryl to chrysoberyl.

In the Považský Inovec Mountains, rare-element mineralization containing $\mathrm{Nb}$-Ta oxide minerals (columbite to tantalite, tapiolite, pyrochlore to microlite and fersmite), in association with beryl, almandine-spessartine, gahnite, and hafnian zircon was described only in a large granite pegmatite dike at Moravany nad Váhom, in the Striebornica Ridge (Uher 1991; Uher et al. 1994; Novák et al. 2000). Accessory Nb, Ta-rich rutile with exsolved titanian ixiolite occurs in the (biotite-) muscovite leucogranite at Malá Kurňa Hill near Kovarce, in the adjacent Tribeč Mountains (Uher and Broska 1992). However, this mineralization is $\mathrm{Ti}, \mathrm{Nb}$-rich and Ta-poor, and represents a different geochemical type in comparison to the Tarich and Ti-poor assemblage at Duchonka. Moreover, occurrences of disseminated Nb, Ta-mineralization (Wrich columbite, W-rich ixiolite, qitianlingite?, Nb-rich ferberite, $\mathrm{Nb}$, Ta-rich rutile and pyrochlore to microlite, in association with cassiterite) are known from Permian highly evolved, specialized S-type topaz-albite granites and adjacent greisenized and albitized rocks at Dlhá Valley near Gemerská Poloma, Hnilec, Betliar and Poproč in the Gemeric Superunit, Central Western Carpathians (e.g. Malachovský et al. 2000). However, this mineralization is connected with specialized ore-bearing granites distinctly enriched in Li, B, F, and with $\mathrm{Nb}, \mathrm{Ti}, \mathrm{W}, \mathrm{Sn}>\mathrm{Ta}$ feature of the Nb-Ta oxide minerals, as opposed to the Duchonka $\mathrm{Ta}>\mathrm{Nb}>>\mathrm{Ti}$, Sn, W pattern.

\subsection{The tantalite-tapiolite association}

The Duchonka pegmatitic leucogranite revealed the presence of accessory columbite to tantalite, tapiolite and hafnian zircon with unusually wide and up to extremely high $\mathrm{Ta} / \mathrm{Nb}$ and $\mathrm{Hf} / \mathrm{Zr}$ fractionation level. Chemical composition of the host leucogranite indicates its distinctive peraluminous character $(\mathrm{ASI}=1.27)$ and relatively high fractionation degree (Tab. 1). Nevertheless, tantalite and especially tapiolite are restricted to the strongly evolved, rare-element granitic pegmatites of the LCT-family (according to the classification of Černý and Ercit 2005), where extreme magmatic fractionation enables the production of volatile- and alkali-rich residual melts, essentially enriched in $\mathrm{Ta}, \mathrm{Hf}, \mathrm{Li}, \mathrm{Rb}, \mathrm{B}$ and other rare lithophile elements (e.g., Černý et al. 1985; London 1990, 2005). The tantalite plus tapiolite assemblage is typical of all types of rare-element granitic pegmatites of the
LCT-family; the association of ferrotapiolite with Ferich columbite-tantalite is mostly characteristic of more primitive beryl type populations (e.g., Černý et al. 1986; Černý 1989; Novák et al. 2000). The tapiolite + Mn-rich columbite-tantalite pairs occur in the most fractionated beryl and especially complex Li, Cs, Ta, F-rich granitic pegmatites worldwide (e.g., Černý et al. 1986, 1992a; Černý 1989; Novák et al. 2000, 2003; van Lichtervelde et al. 2007).

On the other hand, Fe-rich tantalite and ferrotapiolite are scarce in highly evolved, specialized leucogranites, connected with $\mathrm{Sn} \pm \mathrm{W} \pm \mathrm{Nb}-\mathrm{Ta} \pm \mathrm{Li}$ mineralization, where $\mathrm{W}$-(Ti)-rich columbite and ixiolite, $\mathrm{Nb}$, Ta-rich rutile, $\mathrm{Nb}$, Ta-bearing cassiterite, Nb-rich ferberite-hübnerite and locally pyrochlore-group minerals occur (e.g., Johan and Johan 1994; Raimbault et al. 1995; Uher 1998; Breiter et al. 2007). Rare exceptions are found in Ta-rich, specialized rare-element granites in China, where tantalite (Yichun, Suzhou granite) and also tapiolite (Suzhou granite) were reported (Wang et al. 1997; Huang et al. 2002). Accessory tapiolite is present also in the Sn-bearing granite at Rudolfstein, Fichtelgebirge Mountains, Germany (Bernard and Hyršl 2004). In contrast to the above-mentioned tantalite and tapiolite occurrences, the Duchonka pegmatitic leucogranite represents a relatively highly fractionated but still common, non-specialized rock without apparent enrichment in $\mathrm{Li}$, $\mathrm{Rb}, \mathrm{Cs}, \mathrm{B}, \mathrm{P}, \mathrm{Sn}$ or other elements, typical of rare-element pegmatites and ore-bearing granites.

The Fe-rich tantalite compositions with $\mathrm{Ta} /(\mathrm{Ta}+\mathrm{Nb})$ $=0.63-0.72$ and $\mathrm{Mn} /(\mathrm{Mn}+\mathrm{Fe})=0.20-0.27$, which enter the empirically defined natural miscibility gap between tantalite and tapiolite (Černý et al. 1992a), is a particularly striking feature of the Duchonka leucogranite. Despite lack of a XRD determination, the phase very likely belongs to ferrotantalite, and not ferrotapiolite. These anomalous compositions are connected with external parts of the columbite to tantalite crystals (Fig. 5f) and these phases represent a part of the same columbite to tantalite evolutionary trend with a rapid increase of $\mathrm{Ta} / \mathrm{Nb}$ and a stable $\mathrm{Mn} / \mathrm{Fe}$ ratio (Fig. 6). On the contrary, ferrotapiolite occurs as separate grains with different textural pattern and chemistry (Figs 6-7). Such tantalite or tapiolite compositions are exceptional and are considered as metastable in pegmatitic environments (Černý et al. 1992a). However, some "hyper-ferrotantalite" compositions with $\mathrm{Ta} /(\mathrm{Ta}+\mathrm{Nb})$ between 0.62 and 0.97 were described from some rare-element granitic pegmatites in Africa (von Knorring and Fadipe 1981; Baldwin 1989) and the Separation Rapids pegmatite group, Ontario, Canada (Tindle and Breaks 1998). Moreover, W, Ti, Ferich tantalites from the Suzhou and Yichun specialized granites, China, show $\mathrm{Ta} /(\mathrm{Ta}+\mathrm{Nb})$ ratios from 0.50 to 0.73 and from 0.14 to 0.95 , respectively (Wang et 
al. 1997; Huang et al. 2002). All the presented Fe-rich tantalite compositions lie within the field of the tantalite-tapiolite miscibility gap, or even in the tapiolite compositional field (such as ferrotantalite from the Rubicon Mine, Namibia; Baldwin 1989). However, such data are commonly based solely on EMPA without precise XRD identification, and must be taken with a large caution. On the other hand, an empirically determined field of the tantalite-tapiolite miscibility gap (sensu Černý et al. 1992a) is based only on known data from granitic pegmatites, and it can be entered by some natural (stable or metastable) compositions as a consequence of specific PT-X conditions. Based on experimental works, boundaries of the tantalite-tapiolite miscibility gap are controlled by temperature, oxygen fugacity, and phase structural state. The temperature is probably the key factor but the experimental data show inconsistent results (see discussion in Černý et al. 1992a). However, it is reasonable to suggest that the Duchonka pegmatitic leucogranite crystallized at higher temperature compared to classical granitic pegmatites. The tantalite-tapiolite miscibility gap shrinks at such conditions, like in other natural systems of solid solutions or related phases (e.g. Fe-Ti oxide minerals, pyroxenes, feldspars). Moreover, variations of $\mathrm{Ta} / \mathrm{Nb}$ ratios in $\mathrm{Nb}$-Ta oxide minerals strongly depend on $\mathrm{pH}$ of the host pegmatitic melt. The decrease in $\mathrm{pH}$ (increase in acidity) causes an increase in the $\mathrm{Ta} / \mathrm{Nb}$ ratio of the solution and precipitation of $\mathrm{Nb}$-Ta phases (Alexandrov et al. 1985). Similarly, $\mathrm{Ta} / \mathrm{Nb}$ ratio and the span of the tantalite-tapiolite miscibility gap are possibly controlled also by the ASI (molar $\mathrm{Al} /(\mathrm{Ca}+\mathrm{Na}+\mathrm{K})$ ratio) of the host granite or pegmatite melt. Experimental data show a higher solubility of manganotantalite relative to that of manganocolumbite in silicate melts as well as decrease in columbite and tantalite solubility with $\mathrm{Al} /(\mathrm{Na}+\mathrm{K})$ ratio. This explains the $\mathrm{Ta} / \mathrm{Nb}$ enrichment during fractionation and lower saturation level of columbite-tantalite in a peraluminous melt compared to a peralkaline one (Linnen and Keppler 1997; Linnen and Cuney 2005). The Duchonka pegmatitic granite represents such example, where possible synergy of relatively high solidus temperature (compared to common granitic rare-element pegmatites) with an increased fractionation level and strongly peraluminous composition caused precipitation of ferrotapiolite and exceptionally Ta-rich ferrotantalite.

\subsection{Occurrence of hafnian zircon}

Hafnium concentration in accessory zircon, together with the progressive host-rock $\mathrm{Hf} / \mathrm{Zr}$ enrichment, represent well-known indicators of magmatic fractionation (see e.g., Černý et al. 1985). Hafnium-rich zircon is characteristic of leucocratic, highly peraluminous crustal granites with S-type affinity in contrast to the metaluminous man- tle-crustal I-type, and especially (per-) alkaline mantlederived granite of A- or M-type suites (Pupin 2000; Uher 2007). However, the most effective $\mathrm{Zr}-\mathrm{Hf}$ fractionation was observed in the rare-element granitic pegmatites and highly evolved, specialized granites. Generally, the most fractionated granitic pegmatites contain the most Hf-rich zircon, e.g., Tanco, Canada (Černý and Siivola 1980), Mixeriquera, Brazil (Cassedanne et al. 1985), up to exceptional presence of hafnon $\left(\mathrm{HfSiO}_{4}\right)$ at the Muiane pegmatite, Mozambique (Correa Neves et al. 1974). The Hf concentration in the Duchonka pegmatitic leucogranite shows wide variations and unusually high maximum values: from 6 to 23 wt. \% $\mathrm{HfO}_{2}(0.06-0.23 \mathrm{Hf}$ apfu; Tab. 3). Analogous variations and high $\mathrm{Hf}$ concentrations in zircon ( $\sim 5$ to 40 wt. $\% \mathrm{HfO}_{2}$ ) were described from the specialized granites, e.g. Beauvoir, France (Wang et al. 1992), Suzhou and Laoshan, China (Wang et al. 1996, 2000), Podlesí, Czech Republic (Breiter et al. 2006) and several other rare-metal bearing granites (Kempe et al. 1997). Wide $\mathrm{Hf}$ variations in zircon $\left(5-22\right.$ wt. \% $\left.\mathrm{HfO}_{2}\right)$ are also known from the moderately fractionated, granitic pegmatite of the columbite-beryl subtype at Kamzík Hill in Bratislava, Slovakia (Uher and Černý 1998). This trend is supported by experimental data, whereby zircon/hafnon solubility ratio in a metaluminous melts at $800{ }^{\circ} \mathrm{C}$ is c. 0.2 and similar behaviour could be suggested also for peraluminous melts (cf. Linnen and Keppler 2002; Linnen and Cuney 2005). The solubility of zircon is strongly dependent on temperature and melt composition, ranging from several wt. \% Zr levels in peralkaline melts to less than $100 \mathrm{ppm}$ in siliceous peraluminous melts (Watson and Harrison 1983; Linnen and Cuney 2005). The experimental data explain the $\mathrm{Hf} / \mathrm{Zr}$ enrichment coherent with the magmatic fractionation degree in metaluminous to peraluminous systems and relatively low zircon saturation level and temperature in peraluminous, silica-rich granitic to pegmatitic melts. However, the above mentioned $\mathrm{Hf} / \mathrm{Zr}$ trend is relatively rough and irregular due to the presence of other important factors, for example postmagmatic processes (albitization, fluid-driven alteration, metamictization). Therefore, the $\mathrm{Hf} / \mathrm{Zr}$ ratio in zircon as an index of magma fractionation should be used with caution (Kempe et al. 1997; Pérez-Soba et al. 2007). In the case of the Duchonka pegmatitic leucogranite, the wide $\mathrm{Hf} / \mathrm{Zr}$ variations and high $\mathrm{Hf}$ enrichment in zircon could be explained by a coupled effect of high fractionation and a specific, strongly peraluminous local environment. Consequently, the precipitation of the studied Hf-rich zircon is connected with the same specific environment, as the columbite to tantalite and tapiolite crystallization.

Acknowledgements. The authors thank R. Škoda and I. Holický for the electron-microprobe assistance. Valuable comments of both reviewers, M. van Lichtervelde 
and A. Pieczka, as well as M. Novák, a handling editor, improved the quality of the manuscript. This work was supported by the Slovak Research and Development Agency under the contract No. APVV-0557-06.

\section{References}

Alexandrov IV, Krasov AM, Kochnova LN (1985) On the effect of potassium, sodium and fluorine on associations of rock-forming minerals and formation of $\mathrm{Ta}-\mathrm{Nb}$ ore mineralization in the rare-metal granite pegmatite. Geokhim 5: 620-629 (in Russian)

BALDWIN JR (1989) Replacement phenomena in tantalum minerals from rare-metal pegmatites in South Africa and Namibia. Mineral Mag 53: 571-581

Bernard JH, HyršL J (2004) Minerals and Their Localities. Granit, Prague, pp 1-808

Breiter K, Förster HJ, ŠKoda R (2006) Extreme P-, Bi-, $\mathrm{Nb}-$, Sc-, U- and F-rich zircon from fractionated perphosphorous granites: the peraluminous Podlesí granite system, Czech Republic. Lithos 88: 15-34

Breiter K, ŠKoda R, Uher P (2007) Nb-Ta-Ti-W-Sn-oxide minerals as indicators of a peraluminous P- and F-rich granitic system evolution: Podlesí, Czech Republic. Mineral Petrol 91: 225-248

Broska I, Uher P (1988) Accessory minerals of granitoid rocks of Bojná and Hlohovec blocks, the Považský Inovec Mts. Geol Zbor Geol Carpath 39: 505-520

CAssedanne JP, BAPTista A, ČERnÝ P (1985) Zircon hafnifère, samarskite et columbite d'une pegmatite du Rio Doce, Minas Gerais, Brésil. Canad Mineral 23: 543-567

Correa Neves JM, Lopes Nunes JE, Sahama ThG (1974) High hafnium members of the zircon-hafnon series from the granite pegmatites of Zambézia, Mozambique. Contrib Mineral Petrol 48: 73-80

ČERnÝ P (1989) Characteristics of pegmatite deposits of tantalum. In: Möller P, Černý P, SAupé F (eds) Lanthanides, Tantalum and Niobium. Springer-Verlag, Berlin, pp 195-239

ČERNÝ P, ERCIT TS (1989) Mineralogy of niobium and tantalum: crystal chemical relationships, paragenetic aspects and their economic implications. In: MöLler P, ČERnÝ P, SAupé F (eds) Lanthanides, Tantalum and Niobium. Springer-Verlag, Berlin, pp 27-79

ČERNÝ P, ERCIT TS (2005) The classification of granitic pegmatites revisited. Canad Mineral 43: 2005-2026

Černý P, Sirvola J (1980) The Tanco pegmatite at Bernic Lake, Manitoba XII. Hafnian zircon. Canad Mineral 18: 313-321

Černý P, Meintzer RE, Anderson AJ (1985) Extreme fractionation in rare-element granitic pegmatites: selected examples of data and mechanisms. Canad Mineral 23: $381-421$
Černý P, Goad BE, Hawthorne FC, Chapman R (1986) Fractionation trends of the $\mathrm{Nb}$ - and Ta-bearing oxide minerals in the Greer Lake pegmatitic granite and its pegmatite aureole, southeastern Manitoba. Amer Miner 71: 501-517

ČERnÝ P, ERCIT, TS, Wise MA (1992a) The tantalite-tapiolite gap: natural assemblages versus experimental data. Canad Mineral 30: 587-596

ČERnÝ P, NOVÁK M, CHAPMAN R (1992b) Effects of sillimanite-grade metamorphism and shearing on $\mathrm{Nb}$-Ta oxide minerals in granitic pegmatites: Maršíkov, Northern Moravia, Czechoslovakia. Canad Mineral 30: 699-718

Danišík M, Dunkl I, Putiš M, Frisch W, KrÁL J (2004) Tertiary burial and exhumation history of basement highs along the NW margin of the Pannonian Basin - an apatite fission track study. Austrian J Earth Sci 95/96: 60-70

Huang XL, Wang RC, Chen XM, Hu H, Liu CH (2002) Vertical variations in the mineralogy of the Yichun topaz-lepidolite granite, Jiangxi province, southern China. Canad Mineral 40: 1047-1068

IVAničKa J, Havrila M, Kohút M, KováčIK M, Madarás J, Olšavský M, Hók J, Polák M, Filo I, Elečko M, Fordinál K, Maglay J, Pristaš J, Buček S (2007) Geological map of the Považský Inovec Mts. 1 : 50000. Slovak Geological Survey, Bratislava

JoHAN V, JoHAN Z (1994) Accessory minerals of the Cínovec (Zinnwald) granite cupola, Czech Republic Part 1: Nb-, Ta- and Ti-bearing oxides. Mineral Petrol 51: 323-343

KAMENICKÝ J (1956) Report on geological investigation and mapping of northern part of the Považský Inovec Mts. crystalline basement. Geol Práce Zpr 8: 110-124 (in Slovak)

Kempe U, Gruner T, Renno AD, Wolf D (1997) Hf-rich zircon in rare-metal granites: magmatic or metasomatic origin? In: PAPunEn H (ed) Mineral Deposits. Balkema, Rotterdam, pp 643-646

Kohút M, Kumar S, Határ J (2004) New results of the Považský Inovec Mts. granitic rocks study. In: Geochémia 2004. Slovak Geological Survey, Bratislava, pp 57-59 (in Slovak)

KoHút M, KoneČnÝ P, Siman P (2006) The first finding of the iron Lahn-Dill mineralization in the Tatric unit of the Western Carpathians. Mineral Polon Spec Pap 28: 112-114

LiNNEN RL, CunEy M (2005) Granite-related rare-element deposits and experimental constraints on Ta-Nb-W-SnZr-Hf mineralization. In: LINNEN RL, SAMSON IM (eds) Rare-element Geochemistry and Ore Deposits. Geol Assoc Canada Short Course Notes 17: 70-102

Linnen RL, Keppler H (1997) Columbite solubility in granitic melts: consequences for the enrichment and fractionation of $\mathrm{Nb}$ and $\mathrm{Ta}$ in the Earth's crust. Contrib Mineral Petrol 128: 213-227

LinNen RL, Keppler H (2002) Melts composition control of $\mathrm{Zr} / \mathrm{Hf}$ fractionation in magmatic processes. Geochim Cosmochim Acta 66: 3293-3301 
LONDON D (1990) Internal differentiation of rare-element pegmatites; a synthesis of recent research. In: STEIN HJ, Hannah JL (eds) Ore-Bearing Granite Systems; Petrogenesis and Mineralizing Processes. Geol Soc Amer Spec Paper 246: 35-50

LONDON D (2005) Granitic pegmatites: an assessment of current concepts and directions for the future. Lithos 80: 281-303

MAhel M (1986) Geological Structure of the Czechoslovak Carpathians. Part 1: Paleoalpine Units. Veda, Bratislava, pp 1-510 (in Slovak)

MALACHOvskÝ P, Uher P, ĎuĎA R (2000) Nb-W minerals in rare-element granites from Dlhá Valley, the Spiš-Gemer Ore Mountains. Natura Carpat 41: 7-14 (in Slovak)

Novák M, Uher P, Černý P, Siman P (2000) Compositional variations in ferrotapiolite + tantalite pairs from the berylcolumbite pegmatite at Moravany nad Váhom, Slovakia. Mineral Petrol 69: 295-306

NovÁk M, Černý P, Uher P (2003) Extreme variation and apparent reversal of $\mathrm{Nb}$-Ta fractionaction in columbitegroup minerals from the Scheibengraben beryl-columbite granitic pegmatite, Maršíkov, Czech Republic. Eur J Mineral 15: 565-574

Pérez-Soba C, Villaseca C, Tánago JG, Nasdala L (2007) The composition of zircon in the peraluminous Hercynian granites of the Spanish Central System batholith. Canad Mineral 45: 509-527

Pouchou JL, Pichoir F (1985) "PAP“ (phi-rho-z) procedure for improved quantitative microanalysis. In: ARMSTRONG JT (ed) Microbeam Analysis. San Francisco Press, San Francisco, pp 104-106

PUPIN JP (2000) Granite genesis related to geodynamics from Hf-Y in zircon. Trans Roy Soc Edinb, Earth Sci 91: 245-256

Raimbault L, Cuney M, Azencott C, Duthou JL, Joron JL (1995) Chemical evidence for a multistage magmatic genesis of Ta-Sn-Li mineralization in the granite at Beauvoir, French Massif Central. Econ Geol 90: 548-576

Taylor SR, McLennan SM (1985) The Continental Crust: Its Composition and Evolution. Blackwell, Oxford, pp $1-312$

Tindle AG, Breaks FW (1998) Oxide minerals on the Separation Rapids rare-element granitic pegmatite group, northwestern Ontario. Canad Mineral 36: 609-635

UHER P (1991) Be-Nb-Ta pegmatites - a new type of rare- element mineralization in the Western Carpathians. Geol Carpath 42: 331-339

Uher P (1998) Composition of Nb, Ta, Ti, Sn-bearing oxide minerals from the Homolka phosphorus-rich granite, Czech Republic. Acta Univ Carol, Geol 42: 169-172

Uher P (2007) Zircon in pre-Alpine granites and pegmatites of the Western Carpathians: Zr/Hf and Y variations. Bull mineral-petrogr Odd Nár Muz (Praha) 14-15: 187-191 (in Slovak)

Uher P, Broska I (1992) Ti-Nb-Ta minerals in the Tríbeč leucogranite. Miner Slov 24: 271-277 (in Slovak with English abstract)

Uher P, ČERnÝ P (1998) Zircon in Hercynian granitic pegmatites of the Western Carpathians, Slovakia. Geol Carpath 49: 261-270

Uher P, Černý P, NovÁK M, Siman P (1994) Niobium-tantalum minerals from granitic pegmatites in the Malé Karpaty, Považský Inovec and Žiar Mountains, Western Carpathians, Slovakia. Miner Slov 26: 157-164

van Lichtervelde M, Salvi S, Beziat D, Linnen RL (2007) Textural features and chemical evolution in tantalum oxides: magmatic versus hydrothermal origins for Ta mineralization in the Tanco Lower Pegmatite, Manitoba, Canada. Econ Geol 102: 257-276

von Knorring O, FAdipe A (1981) On the mineralogy and geochemistry of niobium and tantalum in some granite pegmatites and alkali granites of Africa. Bull Minéral 104: 496-507

Wang RC, Fontan F, Monchoux P (1992) Minéraux disséminés comme indicateurs du caractère pegmatitique du granite de Beauvoir, Massif d'Échassières, Allier, France. Canad Mineral 30: 763-770

Wang RC, Fontan F, Xu S, Chen X, Monchoux P (1996) Hafnian zircon from the apical part of the Suzhou granite, China. Canad Mineral 34: 1001-1010

Wang RC, Fontan F, Xu S, Chen X, Monchoux P (1997) The association of columbite, tantalite and tapiolite in the Suzhou granite, China. Canad Mineral 35: 699-706

Wang RC, Zhao GT, Wang, DZ, Lu JJ, Chen XM, Xu SJ (2000) Chemistry of Hf-rich zircons from the Laoshan I- and A-type granites, Eastern China. Mineral Mag 64: 867-877

WATSON EB, HARRISON TM (1983) Zircon saturation revisited: temperature and composition effects in a variety of crustal magma types. Earth Planet Sci Lett 64: 295-304 